DedikasiMU (Journal of Community Service)

Volume 3 Nomor, 1 Maret 2021

\title{
UPAYA MENINGKATKAN PENGHASILAN RUMAH TANGGA DENGAN PELATIHAN BANDENG CABUT DURI DI DESA GOSARI KECAMATAN UJUNG PANGKAH KABUPATEN GRESIK
}

\author{
${ }^{1}$ Muhammad Khaniful Umam, ${ }^{2}$ Siti Qozaemah, ${ }^{3}$ Ali Yusak, ${ }^{4}$ Andi Rahmad Rahim, ${ }^{5}$ Sukaris, \\ ${ }^{6}$ Nur Fauziyah

\begin{abstract}
${ }^{1}$ Mahasiswa Program Studi Akuakultur, Universitas Muhammadiyah Gresik
${ }^{2}$ Mahasiswa Program Studi Akuakultur, Universitas Muhammadiyah Gresik

${ }^{3}$ Dosen Prodi Teknik Perkaplan, Universitas Muhammadiyah Gresik

${ }^{4}$ Dosen Program Studi Budidaya Perikanan, Universitas Muhammadiyah Gresik

${ }^{5}$ Dosen Program Studi Manajemen, Universitas Muhammadiyah Gresik

Email : khanif978@gmail.com, siti.qozaemah@gmail.com
\end{abstract} \\ ${ }^{6}$ Dosen Program Studi Pendidikan Matematika, Universitas Muhammadiyah Gresik
}

\begin{abstract}
ABSTRAK
Salah satu permasalahan yang terjadi di Desa Gosari adalah tidak adanya usaha rumah tangga olahan ikan di desa itu, oleh karena itu kita berinisiatif untuk mengadakan pelatihan bandeng cabut duri, Hal itu dikarenakan ikan bandeng memiliki banyak duri sehingga masyarakat kurang menyukai, namun ikan bandeng memiliki kelebihan nutrisi yang tinggi terutama asam lemak tak jenuh Omega-3 $\left(\omega^{3}\right)$ mencapai $14,2 \%$ dan kandungan protein $20 \%$. Sehubungan dengan itu, kegiatan ini bertujuan meningkatkan nilai jual ikan bandeng dan meningkatkan penghasilan rumah tangga melalui kegiatan pelatihan mencabut duri ikan bandeng. Metode yang digunakan adalah kegiatan pelatihan dan pendampingan mencabut duri ikan bandeng yang diikuti oleh ibu-ibu PKK, serta masyarakat sekitar yang memiliki keinginan untuk berwirausaha. Hasilnya adalah ikan bandeng tanpa duri yang dapat dijual ke konsumen atau bisa diolah menjadi produk lainnya. Kesimpulannya adalah ikan bandeng tanpa duri memiliki peluang bisnis yang menguntungkan dengan kenaikan harga jualnya, sehingga dapat meningkatkan industri rumah tangga olahan ikan di Desa Gosari Kecamatan Ujung Pangkah Kabupaten Gresik.
\end{abstract}

Kata Kunci: Ikan bandeng cabut duri, industry rumahan, Desa Gosari. 


\section{DedikasiMU (Journal of Community Service)}

Volume 3 Nomor, 1 Maret 2021

\section{PENDAHULUAN}

Kabupaten Gresik adalah salah satu kabupaten yang menitikberatkan kebijakan pembangunan daerah di sektor perikanan, salah satunya dengan penetapan kawasan Minapolitan. Penetapan kawasan Minapolitan di Kabupaten Gresik di dasarkan pada potensi perikanan yang dimilikinya. Latar belakang dari penetapan kebijakan kawasan tersebut adalah potensi sumber daya alam untuk dikembangkan, khususnya sektor perikanan yang sangat didukung oleh kondisi topografi dan klimatologi wilayah. Kebijakan penetapan kawasan Minapolitanmelalui pengembangan produk unggulan yang kompetitif dan berdaya saing tinggi selama ini diharapkan akan menjadi motor penggerak roda pembangunan daerah dengan memberikan dampak positif secara luas, khususnya dalam peningkatan kesejahteraan masyarakat yang berada di kawasan Minapolitan.

Gresik juga dikenal sebagai salah satu kabupaten sentra perikanan darat, termasuk bandeng. Dari data Dinas Kelautan dan Perikanan Kabupaten Gresik, yang dikutip peneliti Pusat Penelitian Sosial Ekonomi Kelautan dan Perikanan, pada 2014 lalu jumlah produksi bandeng Gresik sekitar 39.545 ton. Adapun luas lahan mencapai 32.000 hektare. Salah satu hasil budi daya ikan air payau di Kabupaten Gresik adalah ikan bandeng (Chanos chanos). Ikan bandeng dari wilayah Gresik lebih disukai dari pada ikan bandeng yang berasal dari wilayah lain karena rasanya yang gurih, dagingnya kenyal, dan tidak berbau atau berasalumpur.

Gizi ikan bandeng menurut Saparinto (2009), dalam $100 \mathrm{~g}$ daging bandeng mengandung $129 \mathrm{kkal}$ energi, $20 \mathrm{~g}$ protein, 4,8 $\mathrm{g}$ lemak, $150 \mathrm{mg}$ fosfor, $20 \mathrm{mg}$ kalsium, $2 \mathrm{mg}$ zat besi, 150 SI vitamin A, dan $0,05 \mathrm{mg}$ vitamin B1. Berdasarkan komposisi gizi tersebut maka ikan bandeng digolongkan sebagai ikan berprotein tinggi dan berlemak rendah. Menurut penelitian

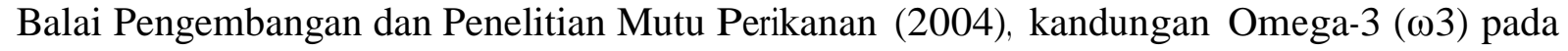
ikan bandeng sebesar $14,2 \%$, melebihi kandungan $\omega^{3}$ pada ikan salmon $(2,6 \%)$, tuna $(0,2 \%)$, dan sardenes mackerel (3,9\%). Berdasarkan hasil penelitian tersebut, ikan bandeng sangat bagus untuk dikonsumsi terutama anak-anak di masa pertumbuhan.

Namun, ikan bandeng memiliki duri (tulang) yang cukup banyak dan kadang berbau lumpur. Umumnya masyarakat menghindari untuk mengonsumsi ikan bandeng dikarenakan duri yang cukup banyak pada dagingnya. Tulang-tulang halus atau duri pada ikan bandeng cukup mengganggu saat dikonsumsi. 


\section{DedikasiMU (Journal of Community Service)}

\section{Volume 3 Nomor, 1 Maret 2021}

Jumlah duri atau tulang halus yang terdapat pada ikan bandeng adalah pada bagian punggung ada 42 pasang duri bercabang yang menempel di dalam daging dekat permukaan kulit luar, bagian dada ada 12 pasang duri pendek, pada rongga perut ada 16 pasang duri, dan bagian perut dekat ekor ada 12 pasang duri kecil.

Tujuan kegiatan Kuliah Kerja Nyata Pengabdian kepada Masyarakat (KKN) ini adalah meningkatkan penghasilan rumah tangga di Desa Gosari melalui metode cabut duri ikan bandeng, dengan kegiatan pelatihan mencabut duri ikan bandeng dan melakukan diversifikasi produk ikan bandeng tanpa duri menjadi produk yang bernilai jual. Pengolahan ikan bandeng tanpa duri merupakan salah satu proses pengolahan diversifikasi produk perikanan. Adapun cara pengolahannya cukup sederhana hanya menggunakan alat utama pinset untuk mencabut duri-duri ikan bandeng. Alat lain sangat mudah ditemukan, yaitu kantung plastik wadah atau loyang, pisau, dan baskom

\section{METODE PELAKSANAAN KEGIATAN}

Metode pelaksanaan, yaitu kegiatan diawali dengan konsultasi dengan pemerintah Desa Gosari, selanjutnya mengetahui sasaran yang akan ditujuh yaitu kepada ibu-ibu PKK dan warga sekitar, setelah mengetahui sasaran yang dijutuh langkah selanjutnya yaitu tahapan pelaksanaan kegiatan dilakukan melalui dua tahapan, yakni tahapan pelatihan dan pendampingan :

1) Tahapan yang pertama yaitu Diawali dengan pemberian materi pelatihan oleh Mahasiswa KKN program studi Akuakultur tentang nilai gizi ikan bandeng, struktur morfologi ikan bandeng, posisi duri ikan bandeng,dan cara-cara mencabut duri yang benar.

2) Tahapan yang kedua yaitu Pendampingan keterampilan mencabut duri bandeng atau praktek langsung mengolah dan mencabut duri ikan bandeng yang didampingi oleh Mahasiswa program studi Akuakultur. Pelaksanaan sosialisasi dan pelatihan pengolahan ikan bandeng (Chanos-chanos) tanpa duri dilaksanakan pada hari Sabtu 29 Maret 2020 pada pukul 15.00 WIB dan bertempat di Balai Desa Gosari. 


\section{DedikasiMU (Journal of Community Service)}

Volume 3 Nomor, 1 Maret 2021

\section{HASIL DAN PEMBAHASAN}

Pelatihan mencabut duri ikan bandeng dan pendampingan kepada masyarakat Desa Gosari, Kabupaten Gresik. Program KKN dilaksanakan oleh mahasiswa KKN bekerja sama dengan pihak PKK Desa Gosari yang dilaksanakan pada sore hari. Masyarakat yang hadir adalah ibu-ibu PKK Desa Gosari. Pelatihan Bandeng Tanpa Duri mendapat respons positif dari PKK. Kegiatan pelatihan dan pendampingan pada masyarakat dilaksanakan pada tanggal 29 Februari 2020 dengan jumlah total peserta 30 orang. Kegiatan ini dilakukan di halaman Balai Desa Gosari, Kecamatan Ujung Pangkah, Kabupaten Gresik. Pelatihan ini dengan tema Pelatihan Bandeng Tanpa Duri. Pelatihan dilaksanakan selama satu hari, diawali dengan pemberian materi secara singkat oleh instruktur, yakni mahasiswa akuakultur. Materi pelatihan meliputi nilai gizi, struktur morfologi, dan posisi duri, cara mencabut duri, serta pengenalan alat dan bahan. Dilanjutkan dengan praktik mencabut duri ikan bandeng menggunakan pinset dengan mengikuti struktur morfologi dan posisi duri ikan bandeng. Praktik mencabut duri ikan bandeng dibantu oleh mahasiswa KKN. Peserta diberikan pula keterampilan tentang proses pembersihan ikan bandeng sekaligus pencabutan duri dapat dilihat pada Gambar 1 dan 2. singkat waktu yang dibutuhkan untuk menyelesaikan pencabutan duri ikan.

\section{Proses Penyiangan Bandeng}

Hal pertama yang harus dilakukan dalam proses penyiangan adalah mencuci semua bandeng yang akan diolah menggunakan air dan es. Tujuannya adalah untuk membersihkan ikan bandeng dari kotoran tanah dan lumpur. Selanjutnya, ikan bandeng disiangi dengan cara membersihkan kotoran dan isi perut ikan dengan cara membelah menjadi bentuk kupu-kupu. Diperlukan kehati-hatian dalam membersihkan isi perut bandeng untuk menghindari pecahnya empedu. Bila empedu pecah, akan membuat rasa ikan menjadi pahit. Ada beberapa pengolah bandeng yang membuang insang. Namun, sebagian lagi ada yang membiarkannya dengan anggapan bahwa insang bisa dijadikan sebagai penyangga bentuk agar penampakan produk terlihat lebih menarik. Pada dasarnya, tahap-tahap penyiangan bandeng adalah sebagaiberikut:

1. Ikan bandeng dibelah pada bagian punggung ( bentuk kupu-kupu ) dari mulai kepala sampai pada pangkal ekor, usahakan pengirisan tidak memotong tulang punggung.

2. Bersihkan bandeng dengan cara membuang isi perut, kotoran,insang. 


\section{DedikasiMU (Journal of Community Service)}

Volume 3 Nomor, 1 Maret 2021

3. Ikan bandeng dicuci agar bandeng juga bersih dari sisa-sisa darah. Pembersihan sisa darah penting dilakukan karena sisa darah yang masih melekat bisa mempercepat terjadinya proses pembusukan baik secara kimia maupun secara biologi. Agar lebih bersih, dilanjutkan dengan perendaman ikan dalam larutan garam $3 \%$.

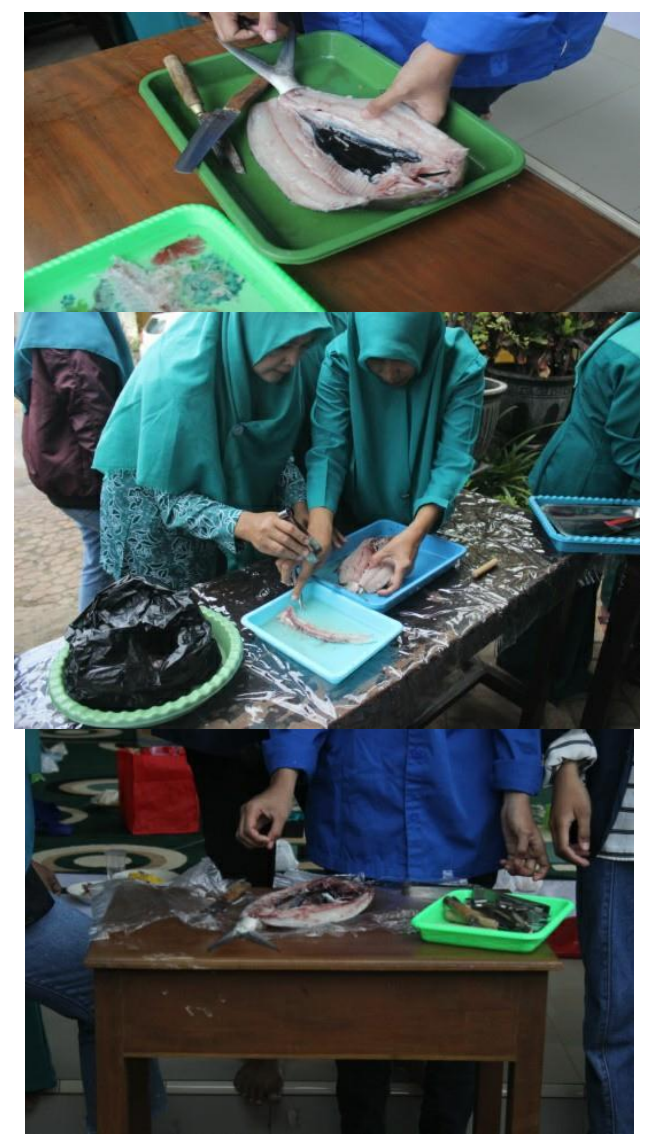

Gambar 1. Penyiangan Ikan Bandeng dan pencabutan tulang utama ikan bandeng

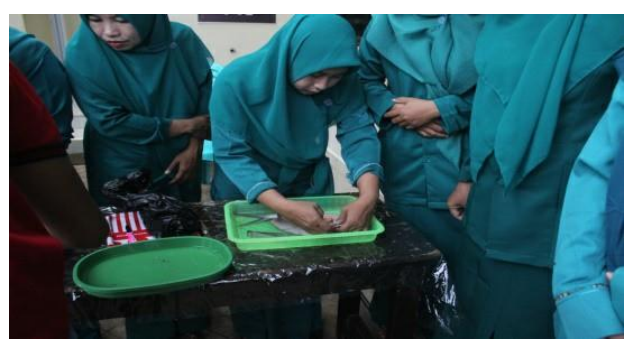

Gambar 2. Pencabutan Duri 


\section{DedikasiMU (Journal of Community Service)}

Volume 3 Nomor, 1 Maret 2021

Pencabutan duri dapat dilakukan secara berurutan sesuai tahapan tersebut atau bisa dengan melakukan dari bagian yang dianggap palingmudah sampai ke bagian yang dirasa paling sulit. Perabaan sebaiknya dilakukan untuk memastikan duri telah tercabut semua. Apabila masih terasa ada duri, segera diambil. Sebaiknya hal ini dilakukan berulang-ulang hingga duri betulbetul tercabut semua.

1. Pencabutan atau penggangkatan tulang belakang Tulang belakang dipatahkan pada bagian ekor selanjutnya ditarik ke atas kebagian kepala, daging ikan ditekan agar tidak ikut tertarik keatas sampai ke bagian kepala.

2. Cabut duri bagian perut sebanyak 16 pasang dengan menggunakan pinset.

3. Mencabut duri di daerah dada dekat kepala (jumlah duri 12 buah).

4. Cabut duri punggung (jumlah duri 42 buah ) diawali pada bagian depan dekat tutup insang.

5. mencabut duri di daerah dekat pangkal ekor (jumlah duri 12 buah).

6. Potong sirip punggung yang diawali dari pangkal punggung sirip punggung hingga sirip terlepas.

7. Perabaan sebaiknya dilakukan untuk memastikan duri telah tercabut semua. Apabila masih terasa ada duri, segera diambil setelah duri betul- betul tercabut semua ikan bandeng tanpa duri siapdikemas.

\section{Keuntungan Usaha Ikan Bandeng Tanpa Duri}

Sesuai dengan harga dasar ikan bandeng yang dibeli di petani tambak seharga Rp 20.000/kg maka setelah dicabut duri bandengnya dijual dengan harga Rp 30.000-35.000/kg. Ikan cabut duri ini laris terjual seluruhnya. Konsumen menyatakan puas membeli ikan bandeng tanpa duri karena duri yang tercabut sudah tidak terlalu mengganggu saat dimakan. Selain itu, rasa ikan bandeng dari Desa Sedayu sangat enak dan gurih, berbeda dengan rasa ikan bandeng dari daerah lainnya. Harga bandeng segar dan biaya produksi, yakni upah mencabut duri ikan bandeng, dan biaya pengemasan (packaging). Apabila dirinci, maka biaya pencabutan $1 \mathrm{~kg}$ (3 ekor ikan bandeng) adalah Rp 10.000. Dengan mempertimbangkan biaya pengemasan maka harga per kilo ikan bandeng tanpa duri dapat ditetapkan adalah Rp 35.000. Jadi bila seorang pekerja mencabut duri ikan bandeng selama 5 jam dari pukul 07.00-12.00 WIB (1 jam dapat mencabut 1-2 kg bandeng) maka bisa memperoleh pendapatan minimal Rp 50.000-100.000 untuk part time/setengah hari. 


\section{DedikasiMU (Journal of Community Service)}

Volume 3 Nomor, 1 Maret 2021

ResikoUsahaIkanBandeng Tanpaduri Ikan bandeng yang berbau tanah bisa menyebabkan rasa bandeng kurang enak. Bila pelanggan memperoleh bandeng yang seperti ini tentu mereka akan kapok membeli lagi. Pemilihan bandeng secara tepat bisa menjadi cara untuk menghindari resiko ini. Aroma tanah pada ikan bandeng sering hanya bisa dideteksi ketika dikonsumsi, oleh sebab itu pastikan pasokan ikan bandeng diperoleh dari sumber yang mempunyai kwalitas ikan bandeng baik.

Promosi dan pemasaran ikan bandeng tanpa duri dapat di jual pada tetangga sekitar dan teman teman kita. Untuk sekala besar dapat menitipkannya di minimarket, di pasar tradisional atau toko-toko. Untuk meningkatkan sales penjualan dan mengenalkan ikan bandeng presto kita bisa juga dengan memanfaatkan media online seperti Facebook, twitter, ikan gratis hingga membuat website khusus perusahaan.

Semoga artikel upaya meningkatkan penghasilan rumah tangga dengan pelatihan bandeng cabut duri di Desa Gosari ini bisa menginspirasi kita semua untuk memulai usaha UKM. Rencana Keberlanjutan Program Diharapkan melalui program kerja KKN, masyarakat mampu mengembangkan sumber daya alam dan potensi laut lainnya menjadi produk yang bermanfaat dan bernilai ekonomi sehingga potensi sumber daya alam ini dapat mengangkat kesejahteraan masyarakat.

\section{KESIMPULAN DAN SARAN}

\section{A. Kesimpulan}

Setelah membuat program kerja ini maka dapat disimpulkan beberapa point, diantaranya adalah sebagai barikut:

1. Peluang usaha bandeng cabut duri sangat besar, karena peminat ikan bandeng sangat banyak

2. Ikan bandeng tanpa duri merupakan ikan bandeng yang sudah dikeluarkan

3. duri dari daging ikan bandeng tersebut

4. Ikan bandeng tanpa duri dapat dikonsumsi oleh kalangan mana saja,baik kalangan bawah, menengah dan kalangan atas.

5. Kelemahan usaha bandeng tanpa duri adalah, apabila terdapat terdapat ikan bandeng yang bau lumpur maka tingkat penjualan akan menurun, selain itu persaingan antar perusahaan. 


\section{DedikasiMU (Journal of Community Service)}

\section{Volume 3 Nomor, 1 Maret 2021}

\section{B. Saran}

Namun yang dapat disarankan untuk semua yang ingin membuka uasaha bandeng cabut duri adalah senbagai berikut:

1) Pilihlah ikan bandeng yang segar dan tidak berbau lumpur.

2) Bukalah usaha yang lokasinya dekat dengan tempat orangramai.

3) Lakukan promosi agar orang-orang mengetahui bahwa kita telah membuka usaha bandeng tanpaduri

\section{DAFTAR PUSTAKA}

Saparinto C. 2009. Bandeng Tanpa Duri dan Cara Pengolahannya. Semarang (ID): Dahara Prize.

Vatria B. 2010. Pengolahan Ikan Bandeng (Chanos chanos) Tanpa Duri. Jurnal Ilmu Pengetahuan dan Rekayasa. Januari 2010: 1823.

Balai Pengembangan dan Pengujian Mutu Hasil Perikanan. 2004. Ikan bandeng dan Produk Diversifikasinya. Jakarta (ID): Departemen Kelautan dan Perikanan. 